\title{
Northern Hemisphere timing of Pliocene/late Miocene climate variations
}

T.D. HERBERT ${ }^{1 *}$, A. TZANOVA ${ }^{2}$, J. B. NOVAK ${ }^{3}$, R. CABALLERO-GILL ${ }^{4}$, , A. CARUSO ${ }^{5}$

${ }^{1}$ DEEPS, Brown Univ., Providence, RI 02912, USA,

(*correspondence: Timothy_Herbert@brown.edu)

${ }^{2}$ DEEPS, Brown Univ., Providence, RI 02912, USA,

Alexandrina_Tzanova@brown.edu

${ }^{3}$ DEEPS, Brown Univ., Providence, RI 02912, USA,

joseph_novak@brown.edu

${ }^{4}$ AOES, George Mason Univ., Fairfax, VA 22030, USA, rcaballero.gill@gmail.com

${ }^{5}$ Scienze della Terra e del Mare, Univ. Palermo, Palermo 90123, Italy, antonio.caruso@unipa.it

Logically, the warm Pliocene and late Miocene should have experienced subdued cryospheric variability under conditions of unipolar glaciation and small variations in temperature and carbon cycling without the amplification of orbital variability that would come with northern hemisphere glaciation. We report here the integration of numerous deep ocean records sampled at high resolution that indicate a robust and spatially coherent pattern of precessional influence in addition to the obliquity signal. Synchronization by oxygen isotope stratigraphy and magnetostratigraphy demonstrates that to first approximation, sea surface temperature (SST) patterns are globally synchronous at the orbital scale. We address the phasing of the precessional response by moving from the wellcalibrated Mediterranean sapropel sequence into the North Atlantic and then globally. Surprisingly, the Northern Hemisphere timing (high summer insolation equivalent to warm SST and deglaciation) dominates the global record. Our results indicate that a) Orbital scale variability in the Pliocene and late Miocene differs distinctively from the " 41 kyr world" of the early to mid-Pleistocene and b) that the Northern Hemisphere can exert control on global climate even without the large amplifying effects of continental ice. 